\title{
A Study on the Impact of Big Five Personality Traits on Consciousness
}

\author{
Akriti Srivastava $^{1}$, Anamika Mishra ${ }^{2}$
}

\section{ABSTRACT}

Personality is the set of psychological traits and mechanisms within the individual that are organized and relatively enduring and that influence their interactions with, and adaptations to, the intra psychic, physical, and social environments. Personality is the factor which influences other functioning of the individuals, keeping this view in mind its relation with consciousness was thought to be explored, which is awareness, the ability to experience or to feel, wakefulness, having a sense of selfhood, and the executive control system of the mind. Hence, this study was designed to understand the relationship between big five personality traits and consciousness, for this, the data was collected from 200 working and non-working males and females in the age range of 22 to 30 years. Sample was chosen from Banasthali Vidyapith, Tonk; Rajiv Gandhi Technical Institute, Raibarely; and Wipro Company, Bangalore. Measures used were selfconsciousness scale (Fenigstein, Scheier \&Buss 1975) which is a 23 item questionnaire and personality questionnaire: NEO Five-Factor Inventory-3 (NEO-FFI-3). This questionnaire was developed by Paul T. Costa, Jr and Robert R. McCrae (1989). The result indicated that openness and conscientiousness are significantly positively related with consciousness and openness emerged out as the significant predictor of consciousness. Also the significant difference was found between males and females in terms of consciousness. This study is unique in its endeavor and creates scope for further exploration in this field.

Keywords: Big Five, Personality Traits, Consciousness

Personality also refers to the pattern of thoughts, feelings, social adjustments, and behaviors consistently exhibited over time that strongly influences one's expectations, self perceptions, values, and attitudes. It also predicts human reactions to other people, problems, and stress.

\footnotetext{
${ }^{1}$ Assistant professor, Department of Psychology, Banasthali Vidyapith, India

2 M.A. Department of Psychology, Banasthali Vidyapith, India

*Responding Author

(C) 2016 I A Srivastava, A Mishra; licensee IJIP. This is an Open Access Research distributed under the terms of the Creative Commons Attribution License (http://creativecommons.org/licenses/by/2.0), which permits unrestricted use, distribution, and reproduction in any Medium, provided the original work is properly cited.
} 
The openness to experience dimension addresses one's range of interests and fascination with novelty. Extremely open people are creative, curious, and artistically sensitive. Those at the other end of the openness category are conventional and find comfort in the familiar. (Robbins, 2008)

The conscientiousness dimension is a measure of reliability. A highly conscientious person is responsible, organized, dependable, and persistent. Those who score low on this dimension are easily distracted, disorganized, and unreliable. (Robbins, 2008) but also conscientiousness dimension can be characterized by reliability, achievement oriented and orderly. (Rothman and Contzer, 2003)

The extraversion dimension captures one's comfort level with relationships. Extraverts tend to be gregarious, assertive, and sociable. Introverts tend to be reserved, timid, and quiet. (Robbins 2008) extraversion categorizes by positive effects and emotions and can be seen as a positive sensation. (Clark and others, 1991)

The agreeableness dimension refers to an individual's propensity to defer to others. Highly agreeable people are cooperative, warm, and trusting. People who score low on agreeableness are cold, disagreeable, and antagonistic. (Robbins, 2008)

The emotional stability dimension often labeled by its converse, neuroticism-taps a person's ability to withstand stress. People with positive emotional stability tend to be calm, selfconfident, and secure. Those with high negative scores tend to be nervous, anxious, depressed, and insecure. (Robbins, 2008)

Consciousness The words "conscious" and "consciousness" are umbrella terms that cover a wide variety of mental phenomena. Both are used with a diversity of meanings, and the adjective "conscious" is heterogeneous in its range, being applied both to whole organisms - creature consciousness-and to particular mental states and processes-state consciousness (Rosenthal 1986, Gennaro 1995, Carruthers 2000).

\section{OBJECTIVE OF THE STUDY}

1. To examine the effect of big five personality factors on consciousness.

2. To find if there is difference between personality of male and female towards consciousness.

\section{Hypotheses}

- Hypotheses 1 Openness would be positively related with consciousness.

- Hypotheses 2 Conscientiousness would be positively related with consciousness.

- Hypotheses 3 Extroversion would be positively related with consciousness.

- Hypotheses 4 Agreeableness would be positively related with consciousness.

- Hypotheses 5 Neuroticism would be negatively related with consciousness.

- Hypotheses 6 Males and females would significantly differ on consciousness. 


\section{METHODOLOGY}

\section{Sample}

A sample of 200 working and non working males and females in the age range of 22 to 30 years were taken. Sample was chosen from Banasthali Vidyapith, Tonk; Rajiv Gandhi Technical Institute, Raibarely; and Wipro Company, Bangalore. For approaching the participants, authorities were contacted and the objective of the study was explained, once permission was obtained participants were approached for data collection on the basis of their readiness and availability.

\section{Measures Used: \\ Self consciousness}

The self-consciousness scale (Fenigstein, Scheier \& Buss 1975) is a 23 item questionnaire which measures individual differences in private and public self consciousness. Self-consciousness is an acute sense of self awareness. It is a preoccupation with oneself, as opposed to philosophical state of self awareness. Participants responded to 23 items on the likert scale ranging from 3 (a lot like me) 43 to 0 (not like me) with total scores ranging from 0 to 69 . The internal reliability of The sub scale is : private self consciousness .75, public self consciousness .84 and social anxiety .79

\section{Personality}

The personality of the participants was measured through the personality questionnaire NEO Five-Factor Inventory-3 (NEO-FFI-3). This questionnaire was developed by Paul t. Costa, Jr and Robert R. McCrae (1989). It measures five factors of personality namely: neuroticism, extraversion, openness, agreeableness and conscientiousness Personality is a set of qualities that make a person (or thing) distinct from another. Participants responded to 60 items on the likert scale ranging from strongly disagree to strongly agree. Total score range from 0 to 240 . The reliability of the inventory is .66 and the validity is .34 to .60

\section{Procedure}

The researcher conducted the research by having the permission to collect data from the above mentioned institution. After the grant of permission the questionnaires were given to the subjects. Participants were given the instructions before handing over the questionnaires. They were informed to answer all the statements. Omission was not allowed. 


\section{RESULTS}

Table 1 showing t- test difference between male and female with respect to consciousness

\begin{tabular}{|l|l|l|l|l|}
\hline consciousness & Mean & df & t & Sig \\
\hline male & 37.62 & 198 & -4.498 & .000 \\
female & 41.94 & & & \\
\hline
\end{tabular}

Perusal of table 1 exhibits the value of $t$ which is -4.498 significantly negatively at .000 levels. This means that the consciousness differs significantly negatively of male and females. In other words, female group feels more consciousness in comparison to male group. The average scores of sample with female group are 41.94 and for the male group is 37.62.

Table 2 showing correlation between Big Five Factors and Consciousness

\begin{tabular}{|c|c|c|c|c|c|c|c|c|}
\hline . & 艿 & $\Leftrightarrow$ & 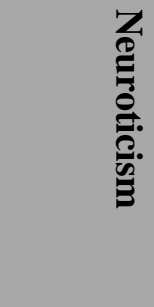 & 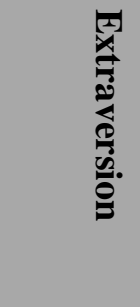 & 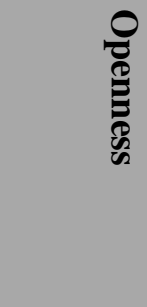 & 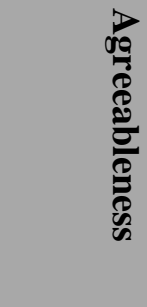 & 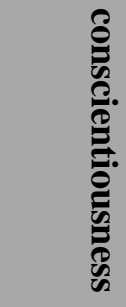 & 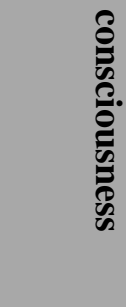 \\
\hline Neuroticism & $\begin{array}{l}24.45 \\
00\end{array}$ & $\begin{array}{l}4.70 \\
46\end{array}$ & 1 & & & & & \\
\hline Extraversion & $\begin{array}{l}29.92 \\
50\end{array}$ & $\begin{array}{l}5.02 \\
250\end{array}$ & $\begin{array}{l}.256^{* *} \\
00\end{array}$ & 1 & & & & \\
\hline Openness & $\begin{array}{l}26.47 \\
00\end{array}$ & $\begin{array}{l}5.47 \\
072\end{array}$ & $\begin{array}{l}.143^{*} \\
0.43\end{array}$ & $\begin{array}{l}.301^{* *} \\
.000\end{array}$ & 1 & & & \\
\hline Agreeableness & $\begin{array}{l}25.75 \\
00 \\
\end{array}$ & $\begin{array}{l}5.42 \\
977 \\
\end{array}$ & $\begin{array}{l}.167^{*} \\
.18 \\
\end{array}$ & $\begin{array}{l}.292^{* *} \\
000\end{array}$ & $\begin{array}{l}.191^{* *} \\
.006 \\
\end{array}$ & 1 & & \\
\hline Conscientiousness & $\begin{array}{l}27.26 \\
00\end{array}$ & $\begin{array}{l}6.67 \\
346\end{array}$ & $\begin{array}{l}.096 \\
.174\end{array}$ & $\begin{array}{l}.363^{* *} \\
.000\end{array}$ & $\begin{array}{l}.438^{* *} \\
000\end{array}$ & $\begin{array}{l}.161 * \\
.023\end{array}$ & 1 & \\
\hline Consciousness & $\begin{array}{l}39.78 \\
00\end{array}$ & $\begin{array}{l}7.11 \\
157\end{array}$ & $\begin{array}{l}.090 \\
204\end{array}$ & $\begin{array}{l}.111 \\
.117\end{array}$ & $\begin{array}{l}.235^{* *} \\
.001\end{array}$ & $\begin{array}{l}.058 \\
.413\end{array}$ & $\begin{array}{l}186^{* *} \\
.008\end{array}$ & 1 \\
\hline
\end{tabular}

Perusal of table 2 shows that consciousness is significantly positively related with openness $(\mathrm{r}=0.235, \mathrm{p}<.001)$ and conscientiousness $(\mathrm{r}=0.186, \mathrm{p}<.008)$ which means the more the openness and conscientiousness the more would be the consciousness, this goes with the direction of the proposed hypotheses that openness and conscientiousness would be positively related with consciousness. 
A Study on the Impact of Big Five Personality Traits on Consciousness

Table 3 showing regression analysis of predictors of consciousness

\begin{tabular}{|l|l|l|l|l|l|l|l|l|l|}
\hline Dependent & Predictor & $\mathbf{R}$ & $\begin{array}{l}\mathbf{R} \\
\text { Square }\end{array}$ & $\begin{array}{l}\mathbf{R} 2 \\
\text { Change }\end{array}$ & $\begin{array}{l}\mathbf{B} \\
\text { value }\end{array}$ & $\boldsymbol{\beta}$ & $\mathbf{F}$ & Sig F & $\mathbf{t}$ \\
\hline Consciousness & Openness & .235 & .055 & .055 & .305 & .235 & 11.564 & .001 & 3.401 \\
\hline
\end{tabular}

Table 4.3 demonstrates regression analysis of the predictors of consciousness. The results of the regression indicated openness explained $5 \%$ of the variance $(R 2=0.055,(F=11.564)=3.401$, $\mathrm{p}<.001)$. Thus it means that openness significantly predicted consciousness $(\beta=.235, \mathrm{p}<.001)$. Therefore the results are consistent with the correlation results and the hypothesis 1 is accepted.

\section{DISCUSSION}

The present study tried to investigate the relationship of big five personality factors with consciousness. The personality correlates of self-consciousness is that a wide array of personality tests has been employed, making the integration and comparison of results cumbersome. Some framework which can integrate the results concerning personality correlates would be helpful. Although not without dissenting viewpoints, proponents of the Five-Factor Model of personality have argued for its comprehensiveness (Costa \& McCrae, 1992; Goldberg, 1993; John, 1990; McCrae, 1991). Developed from a factor analytic tradition (Fiske, 1949; McCrae \& Costa, 1985; Norman, 1963), the Five-Factor Model posits that personality can best be described in terms of the interaction of five traits: Neuroticism, Extroversion, and Openness to Experience, Agreeableness, and Conscientiousness. The debate concerning the relative merits versus weakness of the Five- Factor Model is beyond the scope of this paper, however, it is evident that a considerable amount of personality research is currently being conducted using the Five-Factor framework. Moreover, the test developers have made efforts to understand the relationship between the Five-Factor model and others systems of personality (Costa \& McCrae, 1992).

This study examined the relationship of personality on consciousness. Personality is associated with self-awareness, self- objectification and type of self-consciousness (private and public). On the basis of earlier research, certain hypotheses were made relating to it, and the findings of the study demonstrated that out of five personality traits, openness and conscientiousness were positively related with consciousness which goes with proposed hypothesis. Further analysis, by using step-wise regression, it was also found out that openness emerged out as the significant predictor of consciousness. Though the variance it could explain was mere $5 \%$ percent but it is a significant predictor. This finding goes with studies done by other scholars (Costa \& McCrae, 1992; Goldberg, 1993; John, 1990). Similarly, on the line of the study done by Nadkarni and Herrmann (2010) that conscientiousness is related with consciousness, this study proves the same kind of relationship. Conscientiousness and consciousness relationship had also been examined by other scholars and they also found that there exists a significant relationship (Judge et al., (2002); McCrae \& Costa, (1997); Barrick\& Mount, 1991). On the basis of these findings it can be said that if openness and conscientiousness increases so is the change will be seen on consciousness because consciousness is something like awareness and openness is being open to 
new experiences which means the person who experiences openness is also conscious with what is going on. The relationship between conscientiousness and consciousness came out to be significant because this dimension of personality is concerned with orderliness so if somebody is so concerned with being systematic and orderly then of course, the person will be high on consciousness or one can say being aware.

\section{LIMITATIONS}

Present study has some of the limitations such as the use of only quantitative measure which may not provide an enriched result. Sample size is small and inclusion of more factors would widen the scope of the study. By considering these points future studies can contribute more into this area.

\section{IMPLICATION}

In this modern era everybody wants to be independent, so they work in school, college, and organization. Sometimes it seems that individual's personality effect their work and they cannot pay much attention on their work and than their consciousness is affected, which help as a major factor in shaping their personality. This factor is eluded from the introvert fellows. With openness, conscientiousness and agreeableness, a person can enhance one's character and through these factors one's performance too increases. This has both positive and negative effect on the development of society, so this study is applicable to one and all, who are working in any condition. This study is new in its venture and opens the domain to be studies further. Certain questions were answered and more are yet to be probed.

\section{REFERENCES}

Clark, L.A. And Watson, D. (1991)."General Affective Dispositions in Physical and Psychological Health”. In C.R. Snyder \& D.R. Forsyth (Eds.) Handbook of social and clinical psychology: The health perspective. New York: Pergamum.

Costa, P. T., \& McCrae, R. R. (1992). Four ways five factors are basic. Personality and Individual Differences, 135, 653- Cole, D. A., Martin, J. M., Peeke, L. A., Seroczynski, A. D., \&Fier, J.(1999). Children's over- and underestimation of academic competence longitudinal study of gender differences, depression, and anxiety. Child Development, 70, 459-473. doi:10.1111/1467-8624.00033.

Costa, P. T., \& McCrae, R. R.(1992a). Four ways _ve factors are basic. Personality and Individual Di_erences, 13 (6), 653-665.

Costa, P.T \&Mccrae, R.R. (1992).Revised NEO personality inventory (NEO Pi-R) and NEO five factor inventory (NEO FFI) professional manual. Odessa, Florida: Psychological Assessment Resource.

Costa, P.T., \& McCrae, R.R. (1992). Revised NEO Personality Inventory (NEO PI-R) and NEO-Five Factor Inventory professional manual. Odessa, FL: Psychological Assessment Resources. 
Fiske, D.W. (1949). Consistency of the factorial structures of personality ratings from different sources. Journal of Abnormal and Social Psychology, 44, 329-344.

Judge, T.A., heller, D. \& mount, M.K. (2002). Five-factor model of personality and job satisfaction: a meta-analysis. Journal of Applied Psychology, 87(3):530-541.

Mccrae, R.R. \& Costa, P.T. (1980). Openness to experience and ego level in Loevinger's sentences completion test: dispositional contribution to developmental models of personality. Journal of Personalityand Social Psychology, 39:1179-1190.

Mccrae, R.R. \& Costa, P.T., Jr. (1997). Personality trait structures as a human universal.American Psychologist, 52:509-516.

Mccrae, R.R. (1990). Traits and trait names: how well is openness represented in natural languages? European Journal of Personality, 4:119-129.

Mccrae, R.R. (1991). The five-factor model and its assessment in clinical settings. Journal of Personality Assessment, 57, 399-414.

Mccrae, R.R., \& Costa, P.T. (1985).Updating Norman's "adequate taxonomy": Intelligence and personality dimensions in natural language and in questionnaires. Journal of Personality and Social Psychology, 49, 710-721.

Robbins, Stephen. P\& Judge, Timothy. A, (2008), “Organizational Behavior”, Prentice Hall, pp. 100-110.

Rosenthal, D. 1986. “Two concepts of consciousness.”Philosophical Studies, 49: 329-59.

Rothman. S and Contzer, E.P, (2003), "The Big Five Personality Dimensions and Job Performance”, SA Journal of Industrial Psychology, Vol 29 (1), pp. 68-74. 